\title{
KOOPERATYVUMO KOGNITYVINE IR KOMUNIKACINĖ KATEGORIJOS: ONTOLOGINIS IR GNOSEOLOGINIS ASPEKTAI
}

\author{
Cognitive and Communicative Category of Cooperativity: \\ Ontological and Gnoseological Status
}

\begin{abstract}
SUMMARY
The article reveals the ontological nature of the cognitive and communicative category of cooperativity. The categtory's essence is to be a universal fundamental feature of human society, without which society's successful existence in general and the individual in particular are impossible. At the same time, the ontological status of this phenomenon has been highlighted by finding the prerequisites, sources and methods of cognition involved in the category. It has been suggested that the gnoseological nature of cooperativity deals with the interaction with a partner, respecting the principles of partnership, willingness and ability to work in a team based on fair play due to the standard rules, interest in contacting and ability to obtain mutual benefits.
\end{abstract}

\section{SANTRAUKA}

Straipsnyje nagrinejjamas kooperatyvumo kognityvinės ir komunikacinės kategorijų ontologinis pobūdis. Koopertatyvumas yra universalus, pamatinis visuomenės bruožas, be kurio visuomenės ir atskirų jos individų sẻkmingas gyvavimas būtų neįmanomas. Ontologinis šio reiškinio pobūdis išreikštas objekto pažinimo prielaidose, metoduose ir šaltiniuose. Straipsnyje parodyta, kad kooperatyvumo gnoseologinė prigimtis susijusi su partnerių tarpusavio bendravimu, kuris reiškiasi gebẻjimu dirbti komandoje laikantis partnerystės principu, pagristų sąžiningumu, standartinių taisyklių pripažinimu ir abipusės naudos siekiu. 


\section{INTRODUCTION}

Anthropocentrism as a key principle of modern science in general continues to dominate in linguistics, actualizing new objects of its study through the prism of the linguosynergic paradigm or providing an updated interpretation of already established terms and concepts. These objects of observation are of a special attention, because the cognitive and communicative category of cooperativity belongs to it (R. Benedict, P. Grice, M. Doich, I. Korolyov, A. Kreik, N. Ponomarev, M. Rozov, O. Subetto, M. Tomasello, N. Khudyakova et al.).

The identification of cognitive, pragmatic, psychosociolinguistic, ethical, ideological universal and idioethnic aspects of the implementation of such cognitive and communicative categories as cooperativity, politeness and tolerance in the communicative behaviour of representatives of different linguistic cultures emphasizes the necessity for their systematic and complicated analysis, in particular ontological and gnoseological status.

The object of the research is the cognitive and communicative category of cooperativity; the subject is its ontological and gnoseological status. The aim of the article is to formulate theoretical and epistemological principles for the study of the universal cognitive and communicative category of cooperativity by clarifying its ontological and gnoseological nature.

\section{MAIN TRENDS IN DEVELOPMENT OF COOPERATIVITY CATEGORY AS INTER-DISSIPLANAL NOTION}

It should be noted that cooperativity, as politeness and tolerance, is a constitutive feature of national communicative behaviour, because it turns out that the speaker is inevitably embedded into the system of accepted ways of mapping and evaluating the world in the society, i.e. in the system of culture, because in order to have successful communication it is necessary to use the so-called convention a language that is known to other members of society; it is also necessary to know about the available social views on the world and the rules of relations between people, national-valuable orientations of a linguistic personality. This knowledge is called semantic and prag- matic prepositions (Keenan 1971). In order to have successful interpersonal and intercultural communication, pragmatic pressures are relevant. At the same time, one cannot agree with Yu. Prokhorov that "belonging to a certain culture is determined by the presence of the fundamental stereotypical core of knowledge, repeated in the process of socialization of the individual in society, as well as the peripheral layer (at the level of ethnic culture, but not personality) in the choice of elements" (Прохоров 2006: 14).

Recently, there is a real "scientific boom" in revealing the phenomenon of cooperativity. First of all, the nationalcultural manifestation of politeness in 
various linguistic cultures (Nixdorf 2002; Газизов 2011; Ларина 2009); age features of the formation of politeness as a category of communicative consciousness; the gender aspect of polite behaviour; its conceptual nature (Muders 2009; Фopмановская 2001); communication domains associated with communicative politeness strategies are studied.

Meanwhile, the category of tolerance, characterized by universality, is the subject of research in philosophy, cultural studies, ethnopsycholinguistics (Стернин 2004; Шилихина 2004) sociolinguistics (Крысин 2004), cognitive science and discourse (Корольов 2018), linguopragma-communicative studies (Михайлова 2004), etc. Thus, tolerance is defined in the collective monograph "Cultural practices of tolerance in speech communication" in the following way: it is conceived as a multifaceted cognitive-communicative category that manifests itself in various spheres of human communication and represents one of the fundamental principles of culture associated with pluralism, social and spiritual freedom (Культурные 2004).

In our opinion, hyper-hyponymic (invariant-variant) relations are established between the above-mentioned cognitively communicative categories of cooperativity, politeness and tolerance, because they are constituents (components, structural components etc.) of cooperative one in cognitive and discursive terms of communicative behaviour (Korolyov 2017). Undoubtedly, communication situations, in which politeness and tolerance are realized and are expressed (by the type of expression: formal, neu- tral and informal, as well as by level low, medium and high (Ларина 2009: 163), are of a cooperative nature. In this regard, we propose to consider cognitive and discursive categories of cooperativity and tolerance as varieties of modes of cooperative communicative behaviour and both tactical and strategic tools with significant pragmatic and cooperative potential (Корольов 2014).

During the existence of mankind, the interaction and cooperation of people who are the fundamental signs of homo sapiens led to the search for mutual benefit, the combination of efforts to achieve the best results. We totally agree with the opinion of A. Kreyk and N. Khudyakova that cooperativity is a fundamental feature of mankind, because everyday life demonstrates different variants of behaviour of people in interaction with each other at different levels of society (interpersonal, intergroup, societal) and in many of its spheres (private, productive, cultural, sociopolitical, etc.) (Крейк, Худякова 2014). Scholars also suggest integrating the integrative term cooperativity the following thematically related concepts: solidarity, cooperation, integration, association, community, commonwealth, etc. (Ibid). Obviously, the integrative category of cooperativity has both ontological and epistemological nature, because such virtue is inherent in people who are able to find the best ways for successful interaction, successful communication, implementation of certain strategies, development of their own business, who are open to communication and interested in their welfare, as well as a well-being partner. 


\section{ONTOLOGICAL AND GNOSEOLOGICAL NATURE OF COGNITIVE AND COMMUNICATIVE CATEGORY OF COOPERATIVITY}

According to A. Kreyk and N. Khudyakova, the presence of a tendency towards cooperative behaviour of people is laid both in the natural genetic program of reproduction of the creatures of the homo sapiens and in the sociocultural program formed in the development of mankind (Крейк, Худякова 2014). In particular, U. Maturana and F. Varela, the Chilean physiologists, called "altruistic" and action-specific actions that can be described as favourable for the group, stating the presence of "a certain balance between preserving the individual's life and maintaining the existence of the group as a greater unity, consisting of individuals" (Матурана, Варела 2001: 174). $\mathrm{K}$. Lorenz, a specialist in the field of animal behaviour, remarks on this point: "due to the evolution of many creatures, in order to enable two or many individuals to interact peacefully the aggression must be frozen, the bonds (ties - I.K.) of personal love and friendship appeared, on which the human social relations were built [...]" (Лоренц 1994: 270). In this context, the words of Marcus Aurelius, the Roman emperor, philosopher, representative of the late Stoicism, seems very interesting: "If you even wanted to, you cannot separate your life from humanity. You live in it, by him and for him. We are all created to interact like legs, hands, eyes" (Аврелий Марк). Consequently, the genesis of human orientation towards cooperative behaviour is its nature as a being, and therefore it is important to identify the sociocultural origins of the individual's tendency to cooperate.
The social nature of cooperativity as a philosophical category is postulated by scholars long ago, beginning with the works of Aristotle, the ancient Greek philosopher, who in his article "Politics" noticed that a person is a "public animal", since it can happen / be realized as a person only in the human society. The development of this thought can be traced by turning to the works of other scholars: "There is no greater enemy of loneliness than a human being in its natural state. $\mathrm{He}$ / she involuntarily strives for communication, seeking for closeness and respect from the other: the power of social effects of the individual is so significant that it will not interfere with either its own decision, nor resistance, nor violence or prohibition” (Дидро 1986: 142); “Only humanity [...] transforms each of us into a human being; [...] The natural state for a human being is human society [...]" (Гердер 1977); "Only a human being, who goes beyond the limits of itself in the "world", in "which "he / she" exists, "can realize himself / herself" (Франкл 1990: $70)$; "For the communication of an individualized person with the world there is only one productive path: active solidarity with other people [...] the inherent a human being's desire for unity with another is rooted in the specific conditions of the existence of the human race and it is one of the strongest motivations of human behaviour" (Фромм 1990: 40).

The particular attention is paid to the philosophical aspect of the notions of cooperation and solidarity in the first half of the XIXth century, primarily in 
the works of the founders of sociology O. Comte, the French scientist, and G. Spencer, the English philosopher, and later - E. Durkheim, the famous French sociologist and ethnologist. Theoreticians of the cooperation, represented as practical activity on the transformation of society, became R. Owen, the English philosopher-pedagogue, and S. Fourier, the French philosopher.

With the beginning of search of social mind of the non-capitalist path of development, the idea of cooperation and solidarity became topical in the mid of XIXth century (M. Ziber, M. Kovalevsky, L. Mechnikov, P. Lavrov, E. de Roberti, E. Fromm). Thus, E. Fromm, one of the founders of neofreydism, the German philosopher and social psychologist, noted the following about the preconditions for the unification of people: "in any society, a human being must be united with others if he / she wants to survive or to be protected from the enemies and the dangers of nature, or in order to be able to work and produce means of life" (Фромм 1995: 27).

The idea of cooperation and solidarity as a basis for social development is echoed with the ideas of the unity of O. Khomyakov, the unity of V. Solovyov, the common cause of M. Fedorov, the communitarianism of M. Berdyaev, the spiritual collectivism of S. Franko. According to K. Jaspers, solidarity is one of the most important "conditions of human existence" (Ясперс 1991, 70). E. Fromm points to the significant role of solidarity with the Other. He considers it as "the only productive way to connect an individualized person with the world" (Фромм 1990: 111).
In the 60 s of the XIXth century, the idea of cooperation was developed in Germany and Austria by F. Raiffeisen and G. Schulze-Delizsch in the creation of credit cooperation, which played a significant role in the formation of the so-called cooperative movement, in particular the development and dissemination of the principles of cooperative philosophy and behaviour. They are topical up to this day, because they form the basis for the modern cooperative movement, first of all, such organizations as the International Cooperative Alliance and the World Council of Credit Unions. The authors of the collective work "Competitive Advantages of Different Forms of Cooperation in Transformational Economy: Institutional Aspect" explain the popularity of the cooperative ideology, the viability of which is proved by the history of the cooperative movement, because the cooperation is based on values, the commitment to which ensures the social health of society, its ability to self-organization and self-defence (Щукина 2010).

The question of cooperative values was considered in his works by P. Sorokin, the Russian-American sociologist and cultural scientist, the founder of the theories of social stratification and social mobility. In his opinion, the essence of cooperative values is extremely important in the context of studying the problems of altruism and the priority of supranational values systems, since there have always existed and there are solidarian and antagonistic interactions in groups of interacting individuals (Copoкин 1993: 280). Cooperative values are close and characteristic of the attitude of 
the world, the overwhelming majority of people, regardless of their level of education, social status and activity, ethnic and gender identity, etc. Among the cooperative values and principles, scholars distinguish primarily honesty, openness, social responsibility and care about the Other, which together form the code of cooperative behaviour. It became the fundamental of the most important document - the Declaration of the International Cooperative Alliance on Cooperative Identity, the provisions of which are mandatory for compliance with all cooperative organizations (Щукина 2010).

At the beginning of the XX century, Sh. Zhid, the French economist and social activist, interprets cooperation as a "third way of development" (Gide 1907). In addition, the political and legal theory of solidarity of L. Dugi was popular in France, which was subsequently developed by other solidarityists. According to S. Bulgakov, the Russian philosopher, economist and theologian, the path to solidarity is that "every individuality [...] transforms (reflects - I. K.) and perceives in its own way the same world and the same human nature as its basis. It is not limited, but performed by other individuals. A special source of bliss for individuality lies in the harmony of individuals, in their free love and activity unity" (Булгаков 1993: 153). P. Kropotkin, one of the theorists of anarchism, a historian-publicist, sees cooperation as a form of social self-organization and a non-state social institution: "Humanity is trying $[\ldots]$ to meet its necessities through a free agreement between individuals and groups that seek one goal" (Кропоткин 1990: 53).
The principle of cooperation was also attempted by teachers. In the work of A. Makarenko "Theory and History of Cooperative Movement", general features of cooperatives of all kinds are represented, cooperative principles and values are described, problems of cooperative property are analysed, as well as the importance of the international cooperative movement is revealed (Макаренко 2002), еtc.

From the point of view of linguistic communications, an interpersonal or psychological vectors are important, within which communicative strategies and tactics are developed that regulate harmonious, non-conflict communication. The theory "face conservation" may be regarded as classical one. Based on the theory of speech maxim of G. Leech, its authors P. Braun and S. Levinson divided politeness into positive and negative (Brown, Levinson 1987). The participants in cooperative communication have a common goal, adhering to the communion of a single principle of cooperation (Грайс 1985). Т. Larina proposes to modify Brown-Levinson's theory of "face conservation" in the theory of "distance (distancing) and convergence" (Ларина 2009).

In the aspect of the modern synergetic approach, the question of cooperative processes in nature and society is important, in particular, the significant role of ideas of the phenomenon of cooperative nature in the self-organization of social systems. In this context, one should mention the cooperative theory of sociologists V. Dronov, D. Pashkov et al. who developed a cooperative strategy for the development of modern society 
(Дронов 2000; Пашков 2005). R. Benedict, an American anthropologist, relying on the production of synergy in society, shares the society with low-synergy and high-synergy: "culture is low-synergy when its social structure causes opposition of some of its members to the actions of others, and highly synergistic if the structure encourages the actions of its members for the common good [...]; cultures with high social synergism demonstrate such a social system that promotes mutual benefit for all its members, and - with low social synergies, - where the individual who benefits, overcomes other members of the society (less successful) and attains benefits at their expense [... ]" (Macroy 1999: 215).

According to the philosopher N. Rozov, the fundamental parameters for the sociohistorical dynamics of societies are: 1) degree of diversity of mentality, which is understood as the generalized characteristic of the totality of differences between the values, goals, interests, norms and expectations of members of society, as well as the distance between mentality and social roles; 2 ) cooperative ability, determined by the level of efficiency of the organization of people with differences in mentality, overcoming conflicts between individuals, groups and societies, their involvement in the modes of productive social interaction, coordi- nated activities, in the corresponding social structures (Розов 2002: 168-169). As V. Karasik notes that the degree of self-control of communicants in different situations of communication is marked by significant variability. For example, while talking with close people at home, we usually behave naturally and freely, but in official situations we are considering not only our own statements, but also likely replicas of partners in communication (Карасик 2007: 356). According to Swethonius, Octavian August, the Roman emperor, preparing for a conversation about important matters with Libya, his wife, had the habit of writing down the questions that were necessary to be discussed in advance, and during the conversation he followed this record "to not accidentally tell her too little or too much" (Федорова 2002: 75).

Cooperative ability, in accordance with the concept of N. Rozov, consists of two parameters: 1) coercion that ensures cooperation by subordination of some participants to the interaction of other means of violence, threats, seizure of the monopoly of access to resources and goods; 2) consensus which ensures cooperation, taking into account values, interests and necessities of the autonomous participants politically and economically (ideologically, psychologically - I. К.) (Розов 2002: 169).

\section{COOPERATIVITY AS A COGNITIVE AND COMMUNICATIVE CATEGORY}

Cooperativity as a cognitive and communicative category in communication is realized only through cooperation and interaction with partners. The attentive attitude towards ourselves and our partners, our ability to understand how it is through joint efforts to achieve the results desired by all parties, will undoubt- 
edly develop such an important feature in communicative behaviour as cooperative. Henry Ford, a well-known American industrialist, inventor and owner of car manufacturing factories, commenting on their own livelihood success, argued: "If there's any one secret of success, it's in the ability to get the other person's point of view and see things from that person's angle as well as from your own. - If there is one my secret of success, then this ability to understand the view (point of view) of another person and look at things from both his and my views (Henry Ford)" (Andersen, Forbs).

However, it should be noted that cooperativity, although foreseeing the ability to work in a team, should not contribute to the development of the socalled herd instinct. Through interaction and collaboration, each side of the communication process must achieve its goal and solve its own tasks. In this context, one can appeal to the cooperative activity developed by the team sports, where all are aimed at one overall result of the joint activity, but the individual contribution of each participant depends on whether this result will be achieved. That is why, even in the life-long, professional, it is difficult for communicants to follow the synergistic principle of the "golden section", because it is necessary simultaneously to successfully combine interaction and isolation, the ability and inability to think and act independently, individually for the successful implementation of the cognitive and communicative category of cooperativity in communication. These questions are examined in detail by Rudolf and Kathleen Werderber, the psychologists, professors at the University of Cincinnati (USA), in the work "Psychology of communication. Secrets of Efficient Engagement," which argues that the desire to interact and cooperate in communication is not yet indicative of its ability to do so. According to American experts in the psychology of interpersonal communication, cooperativity is a virtue that each interactive person must apply properly in speech behaviour in order to fulfil its supreme task in its entirety - to create efficient communication through the achievement of the goals of all its participants and the successful implementation of a cooperative and communicative strategy (Вердербер 2010).

In the explanatory dictionaries there is the main archeseme of lexeme cooperation: "1) the action of cooperating: common effort"; 2) "association of persons for common benefit" (MWDT); 1) "when you work with someone to achieve something that you both want"; 2) "willingness to do what someone asks you to do" (LDCE) (lith. kooperăcija: "darbo organizavimo forma, kai daugelis žmonių ar jų kolektyvų dalyvauja tame pačiame arba artimuose darbo procesuose: darbo kooperãcija (DLKŽ). The issue of further intelligence in this area will have a psycholinguistic character, we consider it necessary to refer to the definition of the concept of cooperation in psychology. Thus, according to the Great Psychological Encyclopaedia, cooperation (from the Latin cooperatio - cooperation) is one of the main forms of organization of interpersonal interaction characterized by the 
unification of the efforts of the participants to achieve a common goal, while the simultaneous separation of functions, roles and responsibilities (БПЭ).

For example, in pedagogical psychology, the principle of cooperative interaction between the teacher and the members of the team, as well as within the team itself is one of the most important. In particular, in the work "Children from Heaven," John Gray, an American psychologist, a specialist in the field of interpersonal and family relationships, refers to the upbringing of children and the behaviour of adults, first of all, about the former methods of punishment and the principles of positive parenting. The mainstream of author's thought is the postulating of the idea of binding and exclusivity of the principles of cooperation and interaction between parents and children, through which the family will reign in peace and love, mutual respect and understanding. Even in the title "Children Are From Heaven: Positive Parenting Skills for Raising Cooperative, Confident, and Compassionate Children," J. Gray concentrates the attention of a potential reader on the art of positive parenting, which is essential for the development of a child's cooperative, selfconfidence and sensitivity (Gray 1999).

The interaction and cooperation of people at all times predetermined the search for mutually beneficial, combined efforts to achieve the best and most expected results. In business communication, the code of politeness is one of the foundations of secular communication, because in business communication it is extremely important to adhere to the principles of cooperativity, partnership and attentiveness to the discussed issues. In the proposed British Association of Management Consultancy Consultants, the concept of cooperation, covered in the work of Stephen Cardell "Strategic Cooperation. Creative business course," outlines new opportunities and approaches to cooperation, in particular, it offers four of its models: in the supply chain, based on of abilities, based on the proposal, competitive cooperation. The author pays particular attention to the issues of interaction, cooperation and management in the context of a network economy that can become a motivation to act in e-commerce (Cardell 2003).

\section{CONCLUSIONS}

It may be concluded that the environment (partners, interlocutors), which would be a standard in terms of cooperation, capable of conducting a constructive dialogue / polygon with the desire and ability to achieve the set goals and the desired perlocative one, is the prerequisite for achieving cooperative nature in communication in the so-called "pure" form effect. The ontological nature of the cognitive and communicative category of cooperativity is that, as an object of knowledge, it is a universal fundamental feature of human society, without which it is impossible both its successful existence in general, and individual personality in particular. Considering the ontological nature of the cognitive and com- 
municative category of cooperativity, which involves clarifying the preconditions, sources, boundaries and conditions of the object of cognition, we can assume that its gnoseological status consists in cooperation, interaction with the partner,

\section{Literature and References}

1. Andersen Erika. Henry Ford, Forbs. <http:// www.forbes.com/sites/erikaandersen/2013/05/ 31/21-quotes-from-henry-ford-on-businessleadership-and-life/\#3884fd123700> [accessed on 201808 19].

2. Brown Penelope, Levinson Stephen. 1987. Politeness: Some universals in language usage. Cambridge: Cambridge University Press.

3. Cardell Stephen. 2003. Strategic Collaboration: Creating the Extended Organization (The Management Consultancies Association Series). London: Hodder \& Stoughton.

4. DLKŽ - Dabartinés lietuviu kalbos žodynas 2006. Red. kolegija: S. Keinys (vyr. redaktorius), L. Bilkis, J. Paulauskas, V. Vitkauskas. Vilnius: Lietuviu kalbos institutas. <http://dz.lki.lt/ word/kooperacija/> [accessed on 201808 21].

5. Gray John. 1999. Children are From Heaven: Positive Parenting Skills for Raising Cooperative Confident and Compassionate Children. NY: Harper Collins.

6. Keenan Edward L. 1971. Two Kinds of Presupposition in Natural Language, Fillmore C. J., Langendoen T. (eds.). Studies in Linguistic Semantics: 45-54. NY: Holt, Rinehart and Winston.

7. Korolyov Igor. 2017. National Cooperative Communicative Behaviour: Epistemes, MetaLanguage, Tools, Res Humanitariae 21: 127-142.

8. LDCE - Longman Dictionary of Contemporary English. <http://www.ldoceonline.com/dictionary/cooperation>.

9. Muders Katharina. 2009. Höflichkeit ein universales Konzept? Düsseldorf: GRIN Verlag.

10. Nixdorf Nina. 2002. Höflichkeit im Englischen, Deutschen, Russischen. Marburg: Tectum Verlag.

11. MWDT-Merriam-Webster: Dictionary and Thesaurus. <https://www.merriam-webster.com/ dictionary/cooperation>.

12. Аврелий Марк А. Цитаты и афоризмы Марка Аврелия. <http://citaty.su/biografiya-i-aforizmy-marka-avreliya>. [accessed on 201808 08]. in particular adherence to the principles of mutually beneficial cooperation, readiness and ability to work in a team based on honest playing on generally accepted rules, interest in contact and the ability to win mutual benefit.

13. БПЭ-Большая психологическая энцииклопедия. 2007. Дубенюк Н. (ред). Москва: Эксмо. $<$ http://www.psyoffice.ru/5-psychology-988. htm>. [accessed on 201809 04].

14. Булгаков Сергей Н. 1993. Философия хозяйства In Сочинения: в 2 т. Москва: Наука. Т. 1: 153.

15. Вердербер Рудольф, Вердербер Кэтлин. 2010. Психология общения. Тайны эффективного взаимодействия. Санкт-Петербург: Прайм - Еврознак.

16. Газизов Рафаэль А. 2011. Коммуникативная категория вежливости в немецкой лингвокульmуре: автореф. дис. ... доктора фидол. наук. Уфа.

17. Гердер Иоганн Готфрид. 1977. Идеи к философии истории человечества. Москва: Наука: 230-245.

18. Грайс Герберт П. 1985. Логика и речевое общение, Новое в зарубежной хингвистике. Москва. Вып. 21: 217-237.

19. Дидро Дени. 1986. Принциипь нравственной фихософии или Опьт о достоинстве и добродетели, написанныи милордом Ш. Москва: Мысль. In Сочинения: в 2 т. Т. 1: 142.

20. Аронов Виктор Т. 2000. Кооперативная стратегия в социологии, Элиазер А. В. (сост.), Зарубин В. Г. (отв. ред.). Герияеновские чтения 2000. Актуальные проблемы политологии и социологии. Санкт-Петербург: 143-150.

21. Карасик Владимир И. 2007. Языковые ключи. Волгоград: Парадигма: 356.

22. Корольов Ігор Р. 2014. Когнітивно-комунікативна категорія кооперативності в міжособистісному спілкуванні, Studia Linguistica 8: 369-375.

23. Корольов Ігор Р. 2018. Національна кооперативна комунікативна поведінка: від когніції до дискурсу. Київ: ВПЦ “Київський університет”.

24. Крейк Альфред И., Худякова Наталья И. 2014. Кооперативность как фундаментальный 
признак человечества, Психология, социология u педагогика 6. <http://psychology.snauka. ru/2014/06/3238.> [accessed on 201808 14].

25. Кропоткин Петр А. 1990. Хлеб и воля. Современная наука и анархия. Москва: Правда: 53.

26. Крысин Леонид П. 2004. Толерантность как социолингвистическая категория, Купина Н. А., Михайлова О. А. (отв. ред.). Культурные практики толерантности в речевой коммуникации: 27-32. Екатеринбург: Изд-во УрГУ.

27. Культурные практики толерантности в речевой коммуникацзии. 2004. Купина Н. А., Михайлова О. А. (отв. ред.). Екатеринбург: Изд-во УрГУ.

28. Ларина Татьяна В. 2009. Категория вежливости и стиль коммуникации. Сопоставдение английских и русских лингвокультурных традиций. Москва: Рукописные памятники Древней Руси: 163.

29. Лоренц Конрад. 1994. Агрессия (так называемое “здо”). Москва: Издат. группа “Прогресс", “Универс": 270.

30. Макаренко Анатодий П. 2002. Теория и история кооперативного движения: учебное пособие. 2-е изд. Москва: Маркетинг.

31. Маслоу Абрахам Г. 1999. Дальние пределы человеческой психики. Санкт-Петербург: “Евразия": 215.

32. Матурана Умберто, Варела Франциско. 2001. Древо познания: биологические корни чеповеческого понимания. Москва: Прогресс-Традиция: 174.

33. Михайлова Ольга А. 2004. Толерантность в речевой коммуникации: когнитивные, прагматические и этические основания, Купина Н. А., Михайлова О. А. (отв. ред.). Культурные практики толерантности в речевой коммуникации: 15-26. Екатеринбург: Изд-во УрГУ.

34. Пашков Дмитрий С. 2005. Кооперативные $u$ конкурирующие стратегии в управлении холдингом: социологический аспект: дис. ... канд. социол. наук: Санкт-Петербург.
35. Прохоров Юрий Е. 2006. Национальные социокультурные стереотипы речевого общения и их роль в обучении русскому языку иностранцев. Москва: КомКнига: 14.

36. Розов Николай С. 2002. Философия и теория истории. Москва: Логос. Кн. 1. Пролегомены: 168-169.

37. Сорокин Питирим А. 1993. Система социологии: в 2 т. Социальная аналитика: Учение о строении простейшего (родового) социального явления, Москва: Наука. Т. 1: 280.

38. Стернин Иосиф А. 2004. Проблемы формирования категории толерантности в русском коммуникативном сознании, Купина Н. А., Михайлова О. А. (отв. ред.). Культурные практики толерантности в речевой коммуникациии: 130-149. Екатеринбург: Изд-во УрГУ.

39. Федорова Елена В. 2002. Императорский Рим в лицах. Москва: Слово / Slovo: 75.

40. Формановская Наталья И. 2001. Речевой этикет и вежливость, Русская словесность 3 : 67-72.

41. Франкл Виктор. 1990. Потенцииализм и калейдоскопизм. Москва: Прогресс. In Человек в поисках смысла: 70.

42. Фромм Эрих. 1990. Иметь или быть? Москва: Прогресс: 40, 111.

43. Фромм Эрих. 1995. Бегство от свободы. Москва: Прогресс: 27.

44. Шилихина Ксения М. 2004. Коммуникативная интолерантность в русском общении, Купина Н. А., Михайлова О. А. (отв. ред.). Культурнье практики толерантности в речевой коммуникацุии: 265-272. Екатеринбург: Изд-во УрГУ.

45. Щукина Елизавета С., Дьяконова Т. Е., Худолей А. А. 2010. Конкурентные преимущзества различных форм кооперации в трансформациионной экономике: институциональный аспект: учебное пособие. Оренбург: ОГУ.

46. Ясперс Карл. 1991. Истоки истории и её цель In Смысл и назначение истории. Москва: Политиздат: 70. 